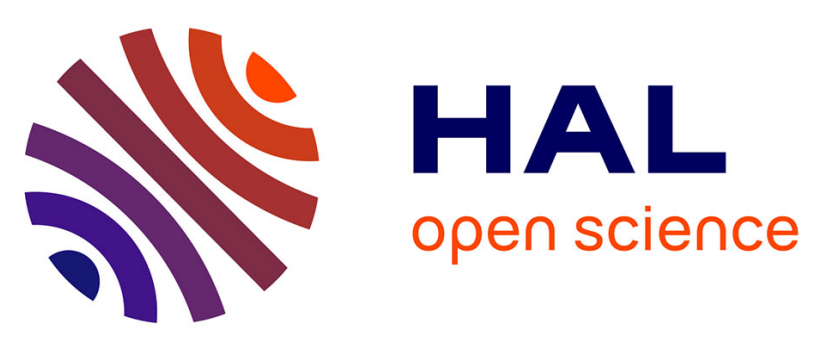

\title{
The Carrers of Social Science Doctoral Graduates in France: the Influence of How the Research was Carried Out
}

Vincent Mangematin, Nadine Mandran, A. Crozet

\section{- To cite this version:}

Vincent Mangematin, Nadine Mandran, A. Crozet. The Carrers of Social Science Doctoral Graduates in France: the Influence of How the Research was Carried Out. European Journal of Education, 2000, 35 (1), pp.111-124. 10.1111/1467-3435.00009 . hal-00424362

\section{HAL Id: hal-00424362 \\ http://hal.grenoble-em.com/hal-00424362}

Submitted on 15 Oct 2009

HAL is a multi-disciplinary open access archive for the deposit and dissemination of scientific research documents, whether they are published or not. The documents may come from teaching and research institutions in France or abroad, or from public or private research centers.
L'archive ouverte pluridisciplinaire HAL, est destinée au dépôt et à la diffusion de documents scientifiques de niveau recherche, publiés ou non, émanant des établissements d'enseignement et de recherche français ou étrangers, des laboratoires publics ou privés. 


\title{
V. Mangematin*, N. Mandran with the collaboration of A. Crozet
}

\author{
Mangematin, V.; Mandran, N.; Crozet, A., 2000, "Careers of PhD in social sciences in France: The influence of how the \\ research was done", European Journal of Education, 35/1, 111-124.
}

\section{Abstract}

The variables determining the attractiveness of social science PhDs remain unknown. A study on the job position of PhD graduates in the social sciences in Grenoble (1984-1996) was carried out to gain insight into the relationship between the research environment during the PhD (funding and time available for the research, i.e. full-time versus part-time), the quality of research (estimated by distinctions and publications) and PhD students' initial training. The conditions in which the doctoral research is carried out have a crucial influence on the job position the graduate is subsequently able to find. PhD graduates are thus locked into trajectories they may not have chosen because of the lack of information needed to make rational decisions. Empirical analysis helps to improve PhD training.

Keywords: PhD graduates, professional trajectories, job position, higher education, university, social sciences.

\section{INTRODUCTION}

Successive cohorts of $\mathrm{PhD}$ students who graduated before 1992 were scarcely enough to fill the increasing number of posts opened in universities and research organisations - a situation that can be explained by growing student populations and the requirements of research that had become a key factor in economic competition. By contrast, post-1992 PhD graduates regularly encounter problems finding jobs.

Although most economic studies conclude that there is a positive relationship between level of qualification and career (Gaudemar et al., 1975), $\mathrm{PhD}$ graduates seem to constitute a very specific group. Despite the high level of their qualifications they have difficulties finding jobs. These problems are a new phenomenon which call for reflection on the nature of the $\mathrm{PhD}$ :

- In what circumstances can the PhD be considered a passport to employment? Is the $\mathrm{PhD}$ a degree like any other or should it also be considered as initial professional experience. PhDs are

\footnotetext{
${ }^{1}$ This research was subsidised by the scientific council of the Pierre Mendes France University in Grenoble.

*Senior researcher, INRA/SERD, Université Pierre Mendès France, BP 47X, 38040 Grenoble Cédex 9, France, Ph : 33 (0)4 76 82 56 86, Fax : 33 (0)4 768254 55, E-Mail : vincent.mangematin@grenoble.inra.fr. We wish to thank PB. Joly, F. Kramarz and A. Richard for their comments on the preceding versions of this text. Of course, any mistakes remain our own.
} 
granted by universities, like other degrees, yet while they are working on their theses $\mathrm{PhD}$ students are employed in a public or private research laboratory. Are PhD students just students or temporary assistants in a research laboratory?

- What are the factors determining PhD graduate's careers? Are they the same for those who go into research and those who find work in another sphere?

- What training policy should the public authorities and universities encourage to make it easier for PhD graduates to find jobs in academia?

Little is known about social science $\mathrm{PhD}$ graduates' career opportunities in France where higher education and research are presumed to be a natural source of employment. Drawing on a retrospective survey of the careers of $\mathrm{PhD}$ graduates from the social science University of Grenoble $^{2}$ (law, economy, education science, management science, political science, history, psychology, and town planning), we point out the factors determining different types of career paths: academic positions, permanent positions outside academia, temporary positions and unemployment. The way in which research for the thesis was done determines future career prospects. The role of training through research is therefore crucial in the professional trajectories of new $\mathrm{PhD}$ graduates.

\section{Scope of the study}

During the last quarter of 1996 we carried out telephone interviews with Grenoble social science university $\mathrm{PhD}$ graduates who had remained in France. Out of a total of $388 \mathrm{PhD}$ graduates identified in the university's records, 105 had returned to their home country, 201 were traced and interviewed and 82 could not be found ${ }^{3}$. The year 1992 corresponds to the point of inflection of the curve. From that year on, $\mathrm{PhD}$ graduates started to encounter problems finding jobs. Thus, given the numbers of subjects available for our study, we divided the group into two cohorts: those who obtained their PhD before 1992 (70 people) and those who obtained it in 1992 or later (130) ${ }^{4}$. Although PhD students who had graduated in 1996 had had less time to find work, the variety of jobs they occupied was not different from that of their predecessors. We therefore retained the year 1996 in the sample.

Since the time required to work on a PhD is limited (especially when the student has a grant), and the duration of temporary employment found by new $\mathrm{PhD}$ graduates is set (mainly research or teaching assistance in Universities ${ }^{5}$ ), reasoning in terms of duration proved difficult to implement for our purposes. We preferred to work on the basis of jobs occupied during the survey, and to piece together the elements of the different $\mathrm{PhD}$ graduates' career paths in relation to jobs occupied.

This paper first makes a general survey of work in this field, in which the nature of $\mathrm{PhD}$ training in the social sciences is explored. It then studies the factors determining the careers of $\mathrm{PhD}$ graduates from Grenoble social science university. The reconstruction of their careers illustrates a lack of flexibility in these trajectories. It also enables us to suggest improvements to the doctoral training policies of social science universities.

\footnotetext{
${ }^{2} \mathrm{PhD}$ at the social science University of Grenoble between 1984 and 1996.

${ }^{3}$ This population is not significantly different from the one found on the following variables: gender, age, duration of thesis, discipline and distinction.

${ }^{4}$ During the years 1990-92, the number of $\mathrm{PhD}$ graduates who arrived in the job market increased substantially due to incentives to promote training through research in the late 1980s. At the same time, the number of posts in higher education and research remained stable and the employment of white collar workers was critically low.

${ }^{5}$ In France, a PhD graduate cannot get a post as teaching or research assistant for more than two years after completion of the PhD.
} 


\section{HYPOTHESES AND DATA}

In economics, studies which analyse the nature of doctoral training can be distinguished in terms of their underlying assumptions. A first group of work on the subject considers doctoral training as a process devoted to academic careers. The only variable analysed is the employment of $\mathrm{PhD}$ graduates in universities. These studies on PhDs focus on an evaluation of the quality of the graduate and, in some cases, on the relationship between this quality and employment in the academic sector. The second group rejects that assumption and focuses on the characteristics of doctoral training and the range of jobs for which PhD graduates can apply.

The PhD: an evaluation of the quality of the degree

Sociologists describe $\mathrm{PhD}$ training as a process of cooptation by peers (Bourdieu, 1984; Soulié, 1996). If we assume that the doctorate is a process of training for the purposes of an academic career, we can evaluate this training in terms of the prestige of the university to which graduates of a particular PhD are recruited. Studies by Niland (1972) and Perry (1994) define criteria for assessing the prestige of the university in which a student does her/his $\mathrm{PhD}$. Niland draws upon the assessment of the National Research Council following the report by A. Cartter (1966). Perry, in his study of agricultural economics PhD programmes, draws upon a postal questionnaire sent to members of the American Agricultural Economics Association. Based on this work, various authors conduct studies with converging results. On the one hand, Hogan (1973) and Perry (1995) show that authors (including PhD graduates) from the most prestigious universities are also the main contributors to the most prestigious journals, particularly in economics. On the other hand, within the confines of the academic sector, different authors show a direct connection between the reputation of the university from which the doctorate was obtained and the post filled by new $\mathrm{PhD}$ graduates.

For these authors, most PhD students fill academic positions after graduating. Their recruitment depends primarily on the visibility of the university and the reputation of its members. We therefore draw on the US experience to formulate hypothesis $\mathrm{H} 1$ :

$H 1$ : The PhD is a degree like any other where the way in which the research is carried out has no influence on the graduate's career.

Ehrenberg (1992) does not discuss this hypothesis in detail in his analysis of US PhD graduates' careers. He does, however, point out the influence of two factors which have hardly been studied in the economic literature: the time taken to do the thesis and the type of funding. He emphasises the lack of knowledge of the relationship between quality of the $\mathrm{PhD}$, expertise acquired and time devoted to doctoral research, and notes that funding modalities are perceived only as signs of quality ex ante, since only the best students are granted federal bursaries. The correlation between the mode of funding during the thesis, the time available for research and the quality of the doctorate is not studied.

\section{Content of $\mathrm{PhD}$ training}

Without a detailed analysis of the way in which the research is done 6 or PhD graduates' careers, some authors study the content of $\mathrm{PhD}$ training and look at whether it meets the expectations of potential employers, for example Hansen (1991) for economics and Johnson (1985) for accounting. Johnson investigates the effects of two radically different training policies, the first based on the training of experts and the second on the acquisition of more general competencies. He shows that the former are less adaptable than the latter, and that the

\footnotetext{
${ }^{6}$ Abeli and Benkin (1987) propose a very interesting analysis of the influence of the way the research is done (funding) on the time taken by students to finish their thesis, but the effects on the recruitment of these graduates are not analysed.
} 
evaluation of competence is more difficult in the case of the latter. Hansen, after having interviewed employers of $\mathrm{PhD}$ graduates outside academia, condemns economic training which is too formalised and does not adequately equip students for dealing with problems that are not also formalised or hardly so. The discrepancy between employers' expectations and the training received by students could be the origin of $\mathrm{PhD}$ graduates' problems finding their first job.

The analysis made by Hansen in the J.E.L. highlights the difference between training given to students (essentially technical) and the independence that employers expect from highly qualified staff. In 1988, in the US, less than $50 \%$ of all $\mathrm{PhD}$ graduates (from all disciplines $45 \%$ for the humanities and $74 \%$ for management science) worked in the academic sector (National Research Council, 1989, cited by Ehrenberg, 1992). The factors determining PhD graduates' careers outside academia nevertheless remain a mystery. The only existing studies concern the employment of graduates in academia (Scott, C.E., 1979). Given that less than half of all $\mathrm{PhD}$ graduates remain in research, it seems relevant to investigate whether the factors determining their careers are identical in research and outside research.

H2 : Factors determining PhD graduates' careers are the same inside and outside academia

The above two hypotheses will be tested on data on all $\mathrm{PhDs}$ from Grenoble social science university (UPMF) who graduated between 1984 and 1996 and remained in France. These graduates' careers are described by means of the following variables:

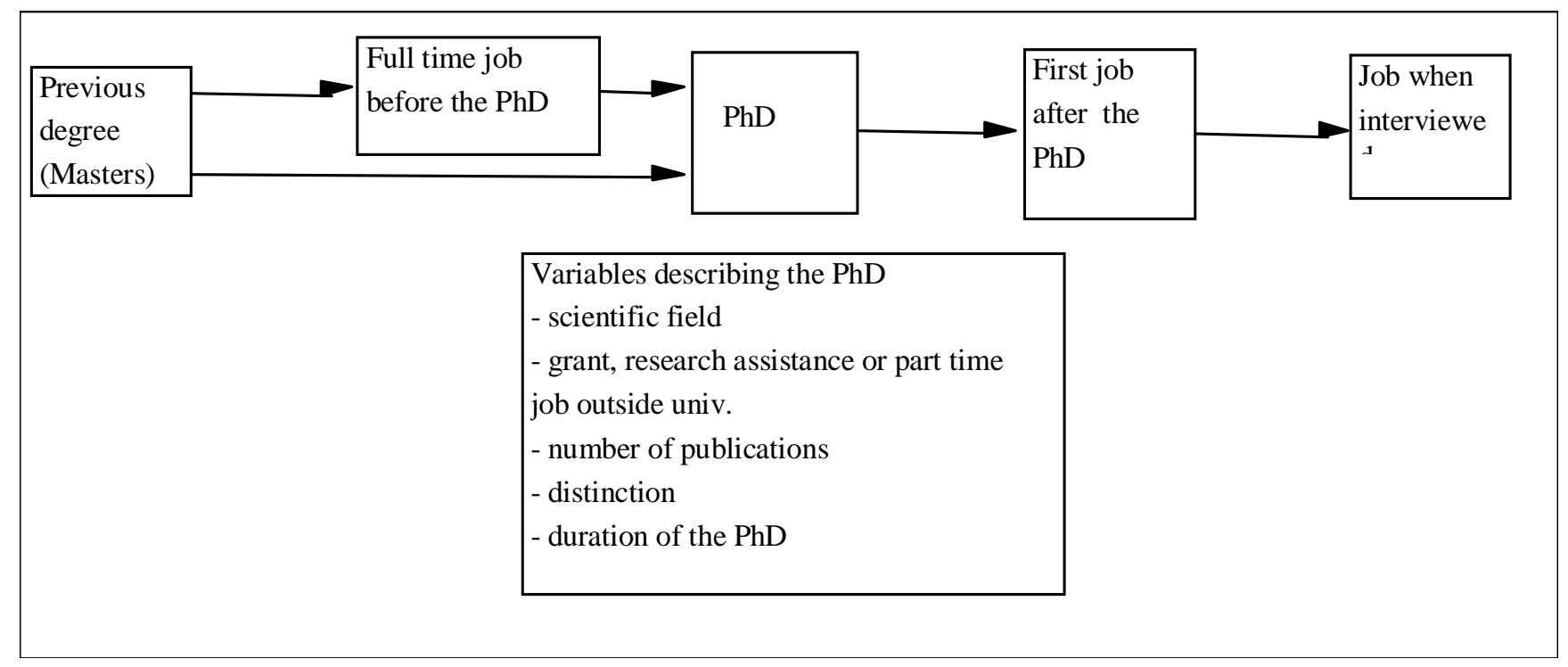

Figure 1: Variables describing PhD graduates’ careers

Like Breneman (1976), we focus our study on a single university. We are unable to test the effects of classification of universities on the recruitment of $\mathrm{PhD}$ graduates since no such classification exists in France, at least not explicitly. On the other hand, we can follow the different phases of PhDs' careers with precision. An analysis of the position occupied at the time of the interview shows that less than half of them worked in research. 
Table 1 : The employment situation of PhDs

\begin{tabular}{|l|l|l|l|}
\hline & $\begin{array}{l}\text { Public } \\
\text { sector }\end{array}$ & $\begin{array}{l}\text { Private } \\
\text { sector }\end{array}$ & in \% \\
\hline Permanent position in academia & 85 & 8 & $46,5 \%$ \\
Permanent position outside academia & 27 & 31 & $29,0 \%$ \\
Temporary position & 21 & 6 & $13,5 \%$ \\
\hline Unemployement & \multicolumn{2}{|c|}{18} & $9,0 \%$ \\
\hline PhDs who work abroad & \multicolumn{2}{|c|}{5} & $2,0 \%$ \\
\hline Total & 201 & $100,0 \%$ \\
\hline
\end{tabular}

The situation worsens markedly after 1992 under the combined effect of increasing numbers of graduates, job stability in the public service, and reduced time for finding a job.

\section{THREE MODELS OF CAREER PATHS}

The construction of models results from the statistical treatment detailed in the annex. The principle of this treatment is relatively stable: it consists of identifying the determining variables to explain the $\mathrm{PhD}$ graduates' current job situation. We have three types of job: academic (model 1), permanent position in the private sector (model 2) and fixed-term contract and unemployment (model 3).

The explanatory variables representing the factors determining careers are:

- Previous degree. This variable has proved to be insignificant.

- Type of funding described in four modalities: grant, research or teaching assistance throughout the $\mathrm{PhD}$; grant or research or teaching assistance during a part of the $\mathrm{PhD}$; permanent position in a firm (teaching in higher education or job in the private sector) during the PhD; short term contract during part of the $\mathrm{PhD}$.

- Distinction (either the best distinction or another one)

- Gender (male, female)

- Number of publications ( $<=2$ and $>2$ )

- Year of PhD (before or after 1992).

Among these variables, some appear to be influential in one model and not in another, e.g. gender for a job in academia.

\section{Model 1 : Recruitment in higher education and academia}

- Even though they have been selected by a university several times, students with a grant for doctoral studies have significantly similar chances of finding a job in academia and working on a short-term contract. By contrast, a research grant strongly reduces the probability of $\mathrm{PhD}$ graduates finding a permanent position outside academia after qualifying. Because social science research posts in the private sector are rare, graduates who studied on a grant find it particularly difficult to find jobs outside academia. Thus, the fact of having a grant cannot be used to distinguish between temporary employment and higher education and research.

- By contrast, any distinction lower than "summa cum laude" (the highest distinction) reduces the probability of being recruited into an academic position. The same applies to the fact of having published fewer than two articles.

- For academic positions, being a woman is a handicap.

- Finally, PhDs who graduated after 1992 are severely disadvantaged compared to those who graduated before that date. The reason is twofold: first because the job market for these graduates started shrinking and secondly because those who graduated after 1992 have had less time to find work and are, in many cases, still looking for a job. 
Model 2 : permanent post outside research in the public or private sector

The model proposed identifies four important variables: funding, distinction, gender and year of graduation. The type of funding seems to be a determining factor for permanent posts outside research. A person who received a research grant in the form of a salary throughout her/his $\mathrm{PhD}$ has greater chances of finding a job outside research. Many $\mathrm{PhD}$ students carry out their research in addition to holding a job (63/203). They are often primary or high-school teachers, have permanent posts in the civil service, or are employed by large companies and work on their thesis during their free time. Thus, they do their $\mathrm{PhD}$ while being employed, and after graduating find it difficult to find work in academia. They end up remaining in their original job, in some cases after a period as teaching assistants on a short-term contract.

In these cases, publications and distinctions play a minor role in the nature of the job occupied since the $\mathrm{PhD}$ graduates are already employed. Job changes after graduation are rare. PhDs seem to have difficulty obtaining value from their training through research. It seems that the positive relationship between fewer than two articles and a job outside research can be interpreted as research work that is not readily recognised by the academic community. We can also assume that the way in which the research was done, i.e. part time, influences the quality of the scientific work and hence distinctions and the propensity to publish.

Finally, the situation before and after 1992 worsens for permanent jobs outside research, even though there is more competition for research posts.

This model must prompt us to apply the utmost caution in an analysis of PhDs' careers. A large proportion of PhD students at Grenoble social science university do their research while in a paid job. Completion of their thesis rarely corresponds to entry into the job market or even to a change of job.

\section{Model 3 : temporary employment}

This model describes a recent situation ${ }^{7}$ (the variable "after 1992" has a strong positive effect). The fact of having had a grant has a positive influence on the fact of finding only temporary employment. In other words, having had a grant increases the chances of post-1992 PhD graduates having a short-term job contract, whether in or outside academia. Moreover, the lower the number of publications, the less stable the employment. People occupying these posts are mainly $\mathrm{PhD}$ graduates who have had temporary positions in academia since 1992.

The fact of having a grant or not is a determining factor in PhDs' careers. Thus, the factors determining careers are different in academia and outside research, and the way in which the research is done influences future employment. The interpretation of these relationships nevertheless necessitates caution. Is the determining factor the fact of being employed while doing a $\mathrm{PhD}$ ? Or is it academic recognition of the $\mathrm{PhD}$, if we consider, like Breneman, that only the best students are recruited in academia?

\section{Specific nature of the $\mathrm{PhD}$}

The type of funding and, more globally, the type of job, if any, that $\mathrm{PhD}$ students had during their research, play an essential role in their future careers. The $\mathrm{PhD}$ is not a degree like any other. The process through which it is obtained strongly influences the value that can be obtained from it. The PhD seems to be more like a first job than like a university exam. Several elements support this point. The candidate's scientific quality is evaluated in terms not only of whether or not $\mathrm{s}$ /he received a distinction, but also of the number of publications. Publication indicates recognition for the scientific quality of the person's work and the "professional" nature of her/his

\footnotetext{
${ }^{7}$ The way in which the survey was conducted introduces a bias. The time taken by people who graduated after 1992 to find jobs is less, while the average time taken by graduates to find jobs is greater than that taken by non-graduates. We note, however, on the sample analysed, that the chances of being recruited into academia diminish with time and that the date of graduation (before/after 1992) has no influence on employment outside research.
} 
approach, since it is the main evaluation criterion in the scientific community. Thus, the number of publications and their quality mean that the student was able, during her/his research, to choose a subject, method and theoretical standpoint recognised by her/his peers. Doing research in a laboratory with a sound reputation in the academic community, where senior researchers are well versed in methods and approaches recognised by the scientific community, is of valuable assistance to $\mathrm{PhD}$ students. In such cases the laboratory plays a key part in the PhD's acquisition of the rules, norms, inclinations, modes of reasoning and behaviour of the academic community. More than any other degree, the $\mathrm{PhD}$ certifies a dual competence: expertise in a particular domain and the ability to use a scientific approach (general) for solving a problem. The research laboratory, as a place in which the PhD student is employed, plays a key role in the socialisation of these students and in the transmission of a scientific ethos 8 (Merton, R.K., 1973). The reputation of the laboratory and of the $\mathrm{PhD}$ supervisor play an essential role in the student's integration into the scientific community. This role was identified by Merton in 1968 as the Mathieu effect ${ }^{9}$

The accruing of greater increments of recognition for particular scientific contributions to scientists of considerable repute and the withholding of such recognition from scientists who have not yet made their mark.

This type of analysis applies only when one considers the PhD to be training through research and for research. For posts outside research, distinctions and publications are not enough to indicate to a potential employer that the candidate's competencies meet the requirements of a certain post.

Hypothesis $\mathrm{H} 1$ is therefore not validated. The research period seems to be a period of learning for a profession, that of researcher or lecturing researcher. The conditions of this learning influence the subsequent value obtained from the degree. On the one hand, it seems that people who do a doctorate in the social sciences while they are employed do not easily get scientific recognition. On the other hand, the training received by $\mathrm{PhD}$ students is hardly formalised. It is closer to on-the-job training, in contact with researchers. $\mathrm{PhD}$ students work while doing their doctoral research do not have the advantage of belonging to laboratories which would enable them to be trained faster.

Hypothesis H2 is not validated either. Career mechanisms differ, depending on the sector. In the academic sector scientific criteria prevail. In non-research sectors experience takes precedence and $\mathrm{PhD}$ students who are employed in university laboratories do not readily have their $\mathrm{PhDs}$ recognised by potential employers as professional experience.

\section{LARGELY INFLEXIBLE TRAJECTORIES}

Do the three models described above cover varied trajectories or are they strongly deterministic from the start of the $\mathrm{PhD}$ ? In other words, do numerous trajectories exist within each of the models?

\footnotetext{
${ }^{8}$ The scientific community is governed by a number of values and norms of an affective nature, which bind scientists together (the ethos). Merton identified four main principles: universalism (any assertion claiming to be the truth, irrespective of its origin, must be subjected to interpersonal criteria defined beforehand); communism (discoveries are a common heritage and the right of the one who produced them to lay claim to them is strictly limited); disinterestedness, and scepticism. All these principles make the possibility of a scientific career open to all, irrespective of the university, team or company to which they belong.

${ }^{9}$ Merton, R.K. (1968): "The Matthew Effect in Science", Science, 159(3810): 56-63.
} 
The above analyses clearly indicate the variables conditioning recruitment into the different types of job that we have identified: employment during the $\mathrm{PhD}$ (grant), number of publications, distinction, gender and duration of the $\mathrm{PhD}$. The chronology of the different steps in PhD graduates' careers enables us to identify their paths more clearly (trajectories leading them to jobs abroad were eliminated).

We have grouped together certain variables to better understand the different people's career paths:

- funding of the $\mathrm{PhD}$ : grant, research or teaching assistance - throughout the duration of the doctoral studies; grant or research or teaching assistance during a part of the $\mathrm{PhD}$; permanent position in a firm (secondary school teaching or employee in private sector) during the $\mathrm{PhD}$; short term contract during part of the PhD.

- First job shortly after graduating: permanent position in academia, temporary position in the private sector and temporary position in academia.

- Current employment: permanent position in academia, permanent position outside academia.

The combination of these different variables gives us a theoretical total of 60 possible trajectories, i.e. funding (4 modalities), first job (5 modalities) and current job (3 modalities). Out of these 60 trajectories, 23 are taken but only 8 are taken by more than 10 people. The diagrams below present the trajectories leading to current employment.

Trajectory 1 : Higher education and research (46\% of the population - 93 people)

The group of PhDs who found work in the academic sector accounts for less than $50 \%$, and this proportion keeps shrinking (from $74 \%$ of the cohort before 1992 to $46 \%$ after 1992 . Taken as an absolute value, the size of this group before and after 1992 is very much the same, which highlights the consequent increase in the number of $\mathrm{PhD}$ graduates). This category of employment is the most significant, numerically. It is also the one for which the most varied trajectories are found.

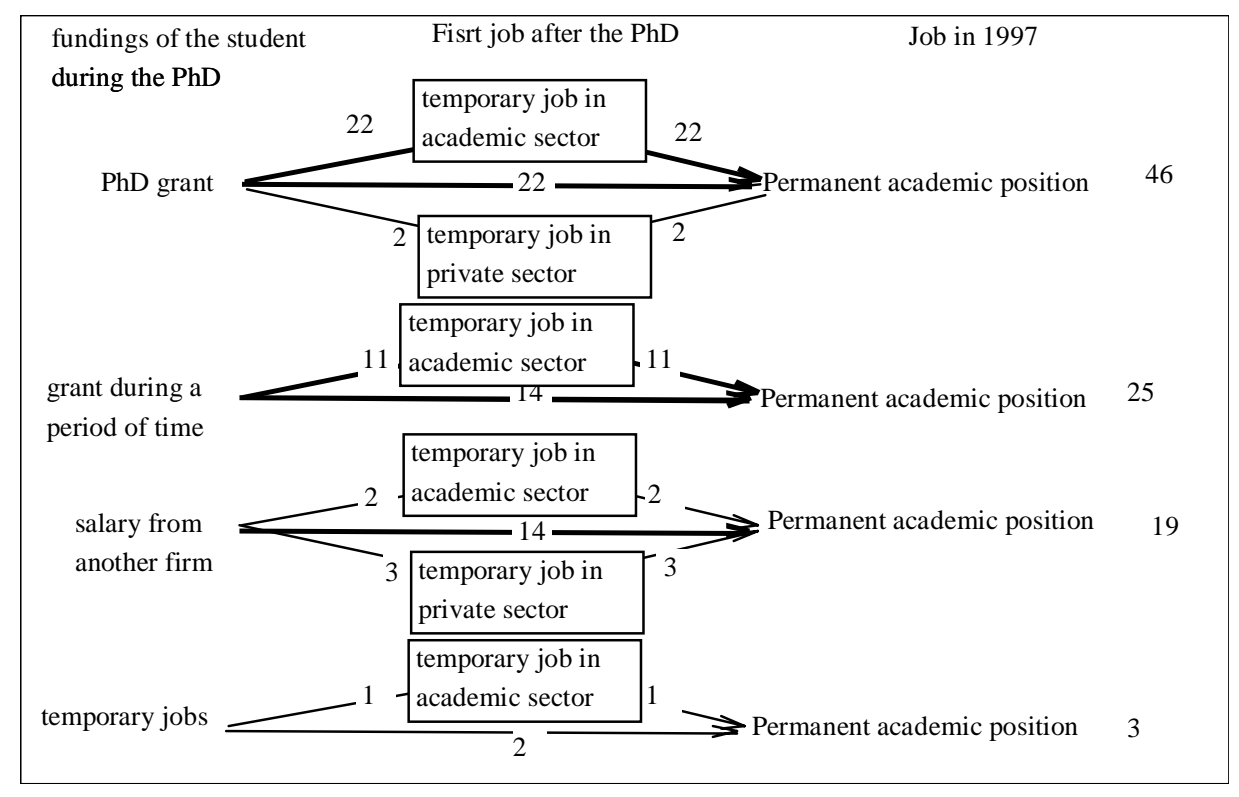

Figure 2 : Trajectories leading to academic positions

This diagrammatic representation of trajectories requires some comment: 
- irrespective of the type of funding, recruitment directly after the $\mathrm{PhD}$ is the most frequent case: $52 / 93$.

- the most frequent trajectory is that of a grant (partial or total) and possibly a temporary position in academia, then a permanent position in academia: 69/93.

- very few PhDs are recruited into academia without first having had a temporary job at a university: 17/93.

Careers in higher education and research seem to be, or to have been, among the most open for $\mathrm{PhD}$ graduates from Grenoble social science university. In fact, they are the careers which have the most trajectories characterised by a change of jobs: move from secondary to higher education or from the private to the public sector. This tendency declines after 1992.

Trajectory 2 : permanent job outside research (31\% of the population)

Out of the $58 \mathrm{PhD}$ graduates from Grenoble social science university with a job outside research, 27 are in the public sector and 31 in the private sector.

For those in the public service, 20/27 already had permanent posts before starting their $\mathrm{PhD}$ and, in most cases, maintained their jobs teaching while working on their thesis. Some of them were given a temporary position as teaching assistants for a maximum period of three years.

About 15 of those in the private sector worked on their thesis while holding a paid job. They were often people who wanted to back up their professional experience, and did not change jobs after obtaining their $\mathrm{PhD}$.

In certain cases, especially in law and psychology, the $\mathrm{PhD}$ provided access to certain professions (in law it was equivalent to the qualification required by advocates; in psychology it enabled doctors to specialise in other functions).

Finally, most of those PhDs who had a grant were employed at some stage while working on their thesis or were recruited before its conclusion.

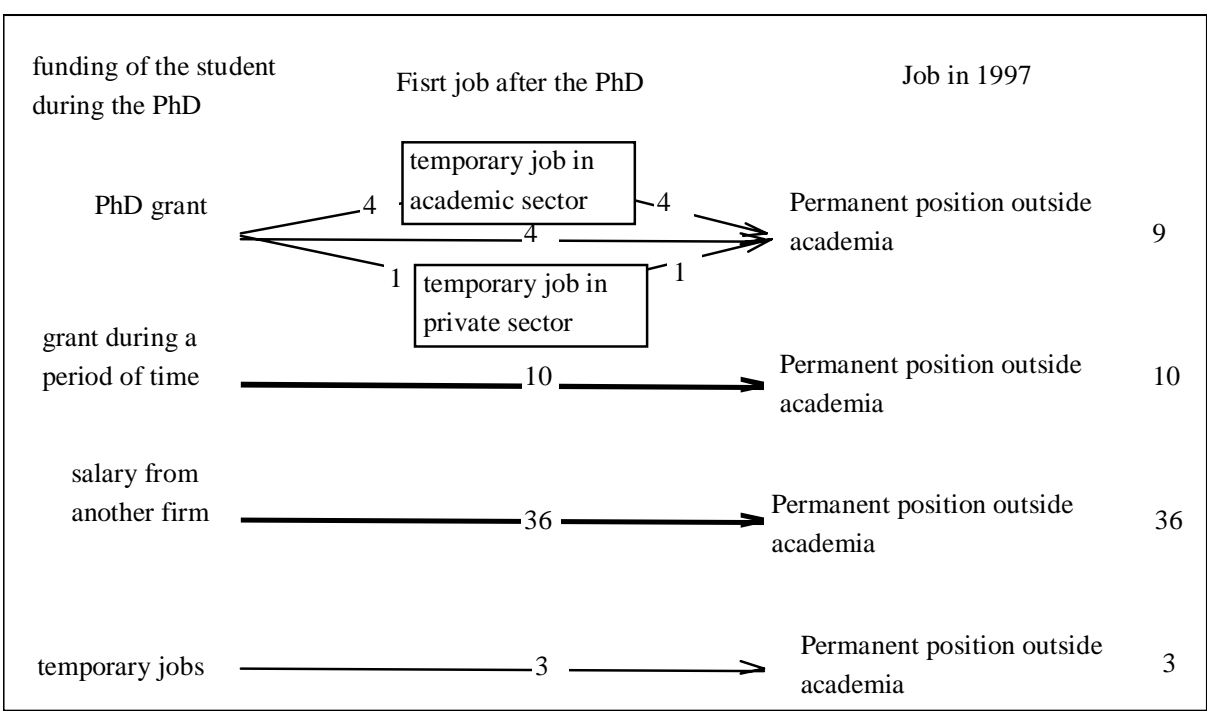

Figure 3 : Trajectories leading to permanent jobs outside research

Only four out of the 71 people whose first job was a temporary position in the public sector found a permanent post in the private sector. Similarly, out of the 132 people who received a grant for their $\mathrm{PhD}$, only 19 had permanent posts in the private sector at the time of the survey. These figures clearly reflect the ambiguity of the PhD. It appears to be university training because it leads to a degree, but that degree is of value only in a particular field: public research in the social sciences. PhDs are often over-qualified for jobs outside research. The careers of graduates who did their thesis while being employed do not progress. 
Trajectory $3:$ PhDs with difficulty finding jobs (23\% of the population)

Out of the $201 \mathrm{PhD}$ graduates interviewed, 18 were unemployed and 27 had temporary jobs. Those who were unemployed had moved around very little and had been at Grenoble social science university for the entire duration of their studies, in 15 out of 18 cases. They had obtained a grant (16/18) during their $\mathrm{PhD}$, a distinction at least and a temporary post as teaching assistant after their $\mathrm{PhD}$ in 9 cases out of 16. Those who failed the competitive examination for a lecturing post, to which they were naturally aiming, were unemployed. At the age of 30 they often turned to the private sector or other posts in the civil service. The profile of these jobless $\mathrm{PhD}$ graduates hardly differs from that of their colleagues who had a lecturing post during their $\mathrm{PhD}$ : a distinction for their thesis, a grant, and publications. The main differences concern previous qualifications and in some cases geographic mobility and a change of focus.

Temporary jobs concern mainly short-term contracts in the public sector and a short-term contract as researcher in the private sector (jobs in a research centre via an association). Most of the $\mathrm{PhD}$ graduates concerned here are young. They graduated after 1992 and apply for lecturing posts. Their profile is very similar to that of unemployed $\mathrm{PhD}$ graduates: no mobility and an essentially academic background without experience other than lecturing and research. 
Figure 4 : Trajectories leading to temporary employment and unemployment

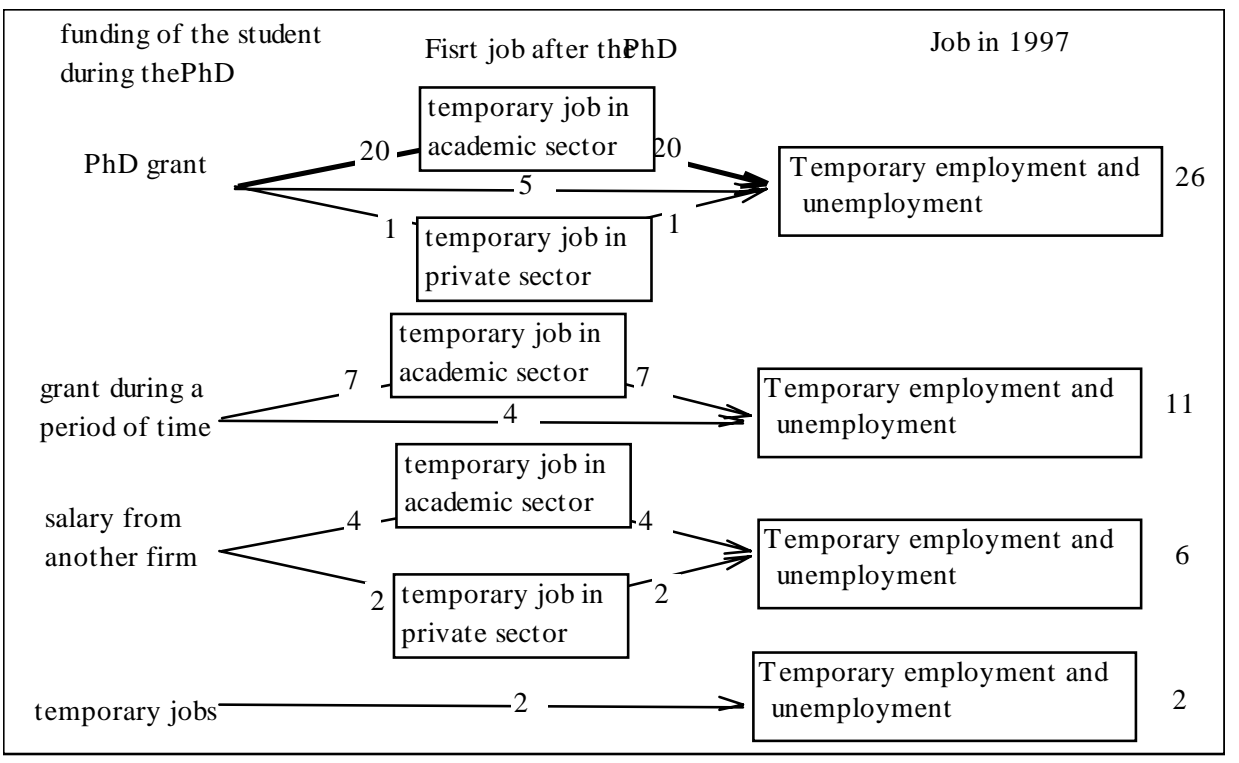

Trajectories with little flexibility

Movement from the private to the public sector and vice-versa

Our analysis of these trajectories reveals that $\mathrm{PhD}$ graduates have difficulty finding work in the private sector, whether research-related or not, when they did their $\mathrm{PhD}$ on a grant. Out of 32 people with a permanent job in the private sector, only six had a grant for the entire duration of their $\mathrm{PhD}$ (out of 86) and only 7 obtained a grant for a limited period during their $\mathrm{PhD}$ (out of 46). 19 out of 32 either had jobs in the private sector throughout their $\mathrm{PhD}$, or found a job in the private sector after qualifying. Thus, there are very few moves from the public to the private sector. They often concern situations in which people with a $\mathrm{PhD}$ highlighted other degrees, obtained before their doctorate, when applying for jobs.

We thus observe a lock-in effect, related particularly to the type of funding and employment during the $\mathrm{PhD}$. It seems that doctorates prepare people for no employment other than academic positions.

This effect is particularly worrying in view of the fact that there are very few moves to the private sector after temporary employment in the academic sector. Since 1992 the increasing number of PhD graduates and the stagnating number of jobs available have created a queue. Our investigation of career paths shows that very few people get out of this situation: one move to a permanent position in the private sector and some recruitment to academic positions. Those $\mathrm{PhD}$ graduates currently in the queue (temporary jobs or unemployed) will have to invent new trajectories.

\section{CONCLUSION}

The analysis of the careers of $\mathrm{PhD}$ graduates in the social sciences reveals the ambiguous nature of the $\mathrm{PhD}$. On the one hand, it is university training like any other, sanctioned by a degree. On the other, the nature of the work involved resembles a process of on-the-job training, so that the $\mathrm{PhD}$ is recognised in some sectors only. As in learning processes, the way in which the research is done plays a determining role in the PhD graduates' first jobs. Thus, the conditions governing their doctoral studies strongly impact on $\mathrm{PhD}$ graduates' future careers. Seen as an initial professional experience, of which the duration is limited mainly by funding (approximately four years), the $\mathrm{PhD}$ produces a high degree of lock-in among young researchers who have obtained a 
grant. Often trained for (academic) research and not by research, $\mathrm{PhD}$ graduates are often unable to obtain value from their degree in the private sector, whether the posts they apply for are research-related or not.

This research is a first step which warrants further attention in two respects:

A rational decision taken by students

The work of Ehrenberg emphasises those elements which enable students to make rational decisions (Manski, 1993) when they plan on undertaking doctoral studies. They base their decision on a cost/benefit/opportunity analysis, taking into account variables such as career opportunities, salaries, funding of the $\mathrm{PhD}$, duration of the research and scientific quality. Empirical results suggest that criteria of academic excellence generally applied by all academics have to be qualified when $\mathrm{PhD}$ graduates apply for jobs in the private sector. If they do not meet academic criteria, $\mathrm{PhD}$ graduates are likely to find themselves trapped in a particular trajectory. Costs of retraining are high and it appears that the PhD must be part of a real career plan and not simply be considered as the continuation of the person's studies.

For students to be fully informed when they embark on doctoral studies, they need to have relevant information on the real nature of the doctorate and on the career prospects afforded by it. What kind of promotions and salaries can they expect after qualifying? Are careers similar for those who directly move into stable jobs and those who have temporary jobs before being recruited? Further research on the determining factors of $\mathrm{PhD}$ graduates' first jobs would be needed to identify the determining factors of their careers.

Such information is currently available only in very few universities. The creation of $\mathrm{PhD}$ graduates' directories should improve the dissemination of information that universities all too often neglect.

University-industry relations and the future of PhD graduates

If the coexistence of two sectors with different recruitment requirements is accepted as an established fact - as empirical studies seem to confirm - then students must re-examine their criteria for choosing a research team. For academic careers, the model described by economists applies perfectly. On the other hand, for careers in industrial research, the extent and quality of the academic research team's relations with industry are essential.

The relationship between academic visibility and the intensity of relations with industry are complex. While Mansfield (1995) establishes the existence of profound synergy between expertise for industry and academic research, Joly and Mangematin (1996) show that relationships between public research laboratories and industry are based on different logics, depending on the laboratory and the aims of those concerned. Not all types of relationship make it possible to benefit from effects of synergy between activities governed by research contracts and academic research.

In the absence of a convergence of analyses on university-industry relations, the only way in which students can choose between various $\mathrm{PhDs}$ is by becoming a $\mathrm{PhD}$ graduate. This type of information ought to exist and be freely available, something which does not seem to be the case in France.

For PhD students to benefit from real on-the-job training that can be of use in the private sector, $\mathrm{PhD}$ supervisors and researchers in the laboratories concerned must have experience in relations with industry. This is not always the case.

We may well wonder what makes researchers recruit $\mathrm{PhD}$ students? Every year 10,000 $\mathrm{PhD}$ students graduate in France, and 40,000 in the US. Yet it seems that French scientific production in all disciplines together does not amount to $25 \%$ of the US scientific production. Are $\mathrm{PhD}$ students not used all too often to make up for a shortage of skilled workers in laboratories? 


\section{BIBLIOGRAPHY}

Abeli, J. \& Benkin, E., (1987), "The effects of Students' Academic, Financial, and Demographic Variables on Time to Doctorate,” Research on Higher Education, 27/1, 3-14.

Beltramo, J.P.; Bourdon, J.; Paul, J.J., (1992), "L'emploi scientifique à l'horizon 2000 : Essai de prospective,” Formation emploi, 45, 33-50.

Bourdieu, P., (1984), Homo academicus, Paris: Ed de Minuit.

Bowen, W.G. \& Rudenstine, N., (1992), In the pursuit of the PhD. Princeton: Princeton University Press.

Breneman, D., (1976), “The PhD Production Process”, Education as an Industry,. Ed. Fromkin, J.T.J., D.T.; Radner, R. Cambridge, MA: Ballinger, 3-52.

Cartter, A., (1966), An Assessment of Quality in Graduate Education , Washington, D.C.: American Council on Education, 1966

Ehrenberg, R.G., (1992), “The Flow of New Doctorates,” Journal of Economic Literature, 30/2, 830-75.

Hansen, W.L., (1991), "The Education and Training of Economics Doctorates: Major Findings of the Executive Secretary of the American Economic Association's Commission on Graduate Education in Economics,” Journal of Econo!mic Literature, 29/3, 1054-87.

Hogan, T.D., (1973), "Rankings of Ph.D. Programs in Economics and the Relative Publishing Performance of their Ph.D.'s: The Experience of the 1960's” Western Economic Journal, 11/4, 429-50.

Johnson, S.B., (1985), "The Economic Function of Doctoral Programs in Accounting: Alternative Theories and Educational Implications,” Accounting Review, 60/4, 736-43.

Joly, P.B. \& Mangematin, V., (1996), "Profile of laboratories, industrial partnerships and organization of R\&D : the dynamics of relations with industry in a large research organization,” Research Policy, 25/4, 901-922.

Gaudemar, J. P., and J. P. Jallade, (1975), Niveau d'éducation et carrières professionnelles, Paris: Cujas.

Mansfield, E., (1995), “Academic research underlying industrial innovations : sources, characteristics and financing.” Review of Economics and Statistics 75, no. 1: 55-65.

Manski, C. F., (1993), "Adolescent econometricians : How do youth infer the return to schooling", C. T. R. Clotfelter, M. (Eds), Studies of supply and demand for higher education. Chicago, The university press, pp. 43-57.

Merton, R.K., (1973), “The normative structure of Science”, Sociology of Science: Theoritical and empirical investigations,. Ed. Merton, R.K. Chicago: Chicago University Press.

Niland, J.R., (1972), “Allocation of Ph.D. Manpower in the Academic Labor Market,” Industrial Relations, 11/2, 141-56.

Perry, G.M., (1995), "Objective Measures of Ph.D. Program Quality in Agricultural Economics,” Review of Agricultural Economics, 17/3, 395-408.

Scott, C.E., (1979), “The Market for Ph.D. Economists: The Academic Sector,” American Economic Review, 69/2, 137-42.

Soulié, C., (1996), "La précarité dans l'enseignement supérieur", Actes de la recherche en sciences sociales. 
ANNEX 1 : FACTORS DETERMINING THE CAREERS OF SOCIAL SCIENCE PHD GRADUATES FROM GRENOBLE UNIVERSITY.

The analysis was carried out by estimating multinomial logit models (Maddala, 1983). The multinomial logit model makes it possible to study how different qualitative variables influence another qualitative variable which may have several modalities (current employment).

The endogenous variable (variable to be explained) is current employment, divided according to three modalities:

- permanent position in academia;

- permanent position outside academia;

- short term contract and unemployment.

Explicative variables that are representative of the factors determining the position obtained are:

- degree before the masters degree and the masters degree, split into two modalities (same region or other region);

- type of funding described in four modalities: grants - research grants, temporary position as teaching assistant, bursaries throughout the $\mathrm{PhD}$; grant during only part of the $\mathrm{PhD}$; employee (secondary school teaching or employment in private sector) during the $\mathrm{PhD}$; employee during part of the $\mathrm{PhD}$.

- distinction (cum laude or other)

- gender (male, female)

- number of publications ( $<=2$ and $>2$ )

- year of PhD (before or after 1992).

Table 2 helps to identify those variables which have a significant influence on the current employment of PhD graduates.

Table 2 : Variables which influence the probability of getting a job in each sector

\begin{tabular}{l|l|l|l|l} 
Variables & $\begin{array}{l}\text { Degree of } \\
\text { freedom }\end{array}$ & Chi 2 & Probability & \\
\hline \hline Constant & 2 & 9,76 & 0,0076 & $* * *$ \\
\hline Previous degree & 2 & 4,09 & 0,1294 & n.s \\
\hline $\begin{array}{l}\text { Place where the first year } \\
\text { of the PhD is done }\end{array}$ & 2 & 2,95 & 0,2293 & n.s \\
\hline $\begin{array}{l}\text { Funding of the student } \\
\text { during the PhD }\end{array}$ & 6 & 40,15 & 0,0000 & $* * *$ \\
\hline Distinction & 2 & 5,14 & 0,0764 & $*$ \\
\hline Gender & 2 & 9,47 & 0,0088 & $* * *$ \\
\hline Number of publications & 2 & 6,42 & 0,0404 & $* *$ \\
\hline Year 1992 & 2 & 16,95 & 0,0002 & $* * *$ \\
\hline \hline Likelihood ratio & 162 & 169,30 & 0,3312 &
\end{tabular}

*** : significant at $1 \%, * *$ : significant at $5 \%,{ }^{*}$ significant at $10 \%$, n.s : not significant.

The table gives the value of Chi2 and the associated probability. These tests enable us to evaluate the significant influence or not of exogenous variables.

The test of the maximum likelihood measures the appropriateness of the model.

The initial hypothesis: HO: exact model, if the associated probability is high, the model is not rejected. For the model, the value of the maximum likelihood is 169,3, with a probability of $0,33 \mathrm{HO}$ is not rejected.

Two variables have no influence on $\mathrm{PhD}$ graduates' careers: the place in which they obtained the degree preceding their Masters degree, and the origin of the Masters. The significant factors 
determining recruitment are: type of funding, year of $\mathrm{PhD}$, number of publications, distinctions and gender. 